\title{
A Retrospective Study: Characteristics and Management of Gonorrhea
}

\author{
Indah Purnamasari ${ }^{1}$, Dwi Murtiastutik ${ }^{1}$, Muhammad Yulianto Listiawan ${ }^{1}$, Evy \\ Ervianti $^{1}$, Rahmadewi ${ }^{1}$, Budiono ${ }^{2}$, Astindari ${ }^{1}$, Maylita Sari ${ }^{1}$, Septiana Widyantari ${ }^{1}$, Afif \\ Nurul Hidayati ${ }^{1}$ \\ ${ }^{1}$ Department of Dermatology and Venereology, Faculty of Medicine, Universitas Airlangga, Dr. \\ Soetomo General Academic Teaching Hospital, Surabaya, Indonesia \\ ${ }^{2}$ Department of Public Health Sciences, Faculty of Medicine, Universitas Airlangga, Surabaya
}

\begin{abstract}
Background: Gonorrhea (GO) is a sexually transmitted infection that remains an important clinical and public health problem worldwide. Its incidence tends to increase both in males and females. Given the scale of the public health impact of GO, the selection of appropriate therapy is essential. Purpose: This study aimed to evaluate the characteristics, management, and recovery of gonorrhea patients. Methods: The research material was obtained from the medical record of gonorrhea patients at the Sexually Transmitted Infections (STI) Outpatient Clinic, Dermatology and Venerelogy Department, Dr. Soetomo General Academic Teaching Hospital, Surabaya, from January 2016 to December 2018. Result: We found 84 new GO patients $(0.02 \%)$ out of the total new outpatients at the Dermatology and Venereology Department, Dr. Soetomo General Academic Teaching Hospital, Surabaya. Most of them were males (92.9\%), 17-25 years age group (52.4\%), unmarried (67.9\%), and heterosexual (90.5\%). The majority of therapy is dual therapy, was combination of doxycycline and cefixime (78\%). Only 34 patients (40.5\%) attended the follow-up visits, and $94.1 \%$ of them recovered, and $5.9 \%$ presented with cystitis. Conclusion: The characteristics features of GO varies in each variable. One of important to control GO is provide effective and appropriate treatment and routinely clinical and laboratories were needed control.
\end{abstract}

Keywords: gonorrhea, Neisseria gonorhoeae, characteristics, management.

Correspondence: Afif Nurul Hidayati, Department of Dermatology and Venereology Faculty of Medicine, Universitas Airlangga, Dr. Soetomo General Academic Teaching Hospital/Universitas Airlangga Teaching Hospital, Surabaya, Jl. Mayjen Prof. Dr. Moestopo No. 6-8 Surabaya 60131, Indonesia. Phone: (031) 5501609, e-mail: afif_nurulhidayati@fk.unair.ac.id.

\section{BACKGROUND}

Gonorrhea (GO) is an infection caused by Neisseria gonorrhoeae, gram-negative bacteria. It remains one of the most common sexually transmitted diseases in developing countries that particularly affects teenagers and young adults. Gonorrhea can affect the genitals, anus, or pharynx. It can be acquired through vaginal, anal, and oral intercourse as well as transmitted vertically from mother to child during vaginal birth. ${ }^{1,2}$

The prevalence of GO varies widely among communities and populations. World Health Organization (WHO) estimates 78 million gonococcal infections annually worldwide. 1,3,4 Gonorrhea infection in Indonesia was found highest of all types of Sexually Transmitted Infections (STIs) with the epidemiology of patients were mostly in 15-24 years age group. ${ }^{5}$

The high risk for GO especially in the adolescent age group, because of their risk sexual behavior such as multiple sexual partners, female sex worker, homosexual and absence of condoms. ${ }^{3}$ According to an investigation conducted among Roma youth (aged 1524 years) in Serbia during the year 2010, risk sexual behaviors were highly prevalent, especially among male subjects. In Belgrade, out of male Roma youth, $36.2 \%$ had sexual debut before the age of 15 years, $53.9 \%$ had more than one sexual partner in the past year, $11.5 \%$ had engaged in commercial sex, and $4.0 \%$ reported having anal sex with other men. ${ }^{6}$ The results study in 12 major cities in Indonesia show that 10-31\% of unmarried adolescents group have had sexual intercourse. $^{7}$

Gonorrhea infections in women are often asymptomatic and the symptoms results in unrecognized and untreated infection that may lead to serious complications, including pelvic inflammatory disease, ectopic pregnancy and infertility. Infection with $N$. gonorrhoeae has also been associated with increased HIV shedding. ${ }^{2,3,4}$

The major public health needs to control gonorrhea is an effective and appropriate treatment. 
Appropriate therapy for gonorrhea (i.e., safe, highly effective, single-dose, and affordable) is challenging as Neisseria gonorrhoeae developing resistance to antimicrobial therapies. ${ }^{3,8,9}$

Based on the history of the gonococcus and will almost certainly present significant future challenges to the treatment and control of gonococcal infections and their complications. This study aimed to evaluate the characteristics, management, and recovery of GO patients at STI Division, Dermatology and Venerology Department, Dr. Soetomo General Academic Teaching Hospital from January 2016 to December 2018

\section{METHODS}

This was a descriptive retrospective study. The data were collected from new GO patients' medical records, including identity, history taking, examination, diagnosis, treatment, follow-up, and counseling with a cross-sectional approach. This study has obtained ethical clearance from the Ethical Committee of Dr. Soetomo General Academic Teaching Hospital Surabaya in October 2019.

\section{RESULT}

There were 84 new GO patients in 2016-2018, contributing to $3.3 \%$ of the total patients at the STI Division or contributing to $0.2 \%$ of 45,178 patients at the Dermatology and Venerology Department. Most of the new GO patients - 44 patients $(52.4 \%)$ - were in the 17-25 years age group. The youngest patient was 3 years old, and the oldest was 55 years old. Most of the new patients were males $(92.29 \%)$, followed by females $(7.1 \%)$.

We found that most of the GO patients $(75 \%)$ were unmarried, consisting of $25(83.3 \%)$ patients in 2016, 21 (80.8\%) patients in 2017, and 17 (60.7\%) patients in 2018 (Fig. 1); Most of the GO patients (53\%) had girlfriends/boyfriends as their sexual partner, consisting of 19 (59.4\%) patients in 2016, 15 (53.6\%) patients in 2017, and $14(46.7 \%)$ patients in 2018 (Fig. 2); Most of GO patients (90.5\%) identified themselves heterosexuals, followed by homosexuals $(3.6 \%)$, and bisexuals (3.6\%) (Fig. 3).

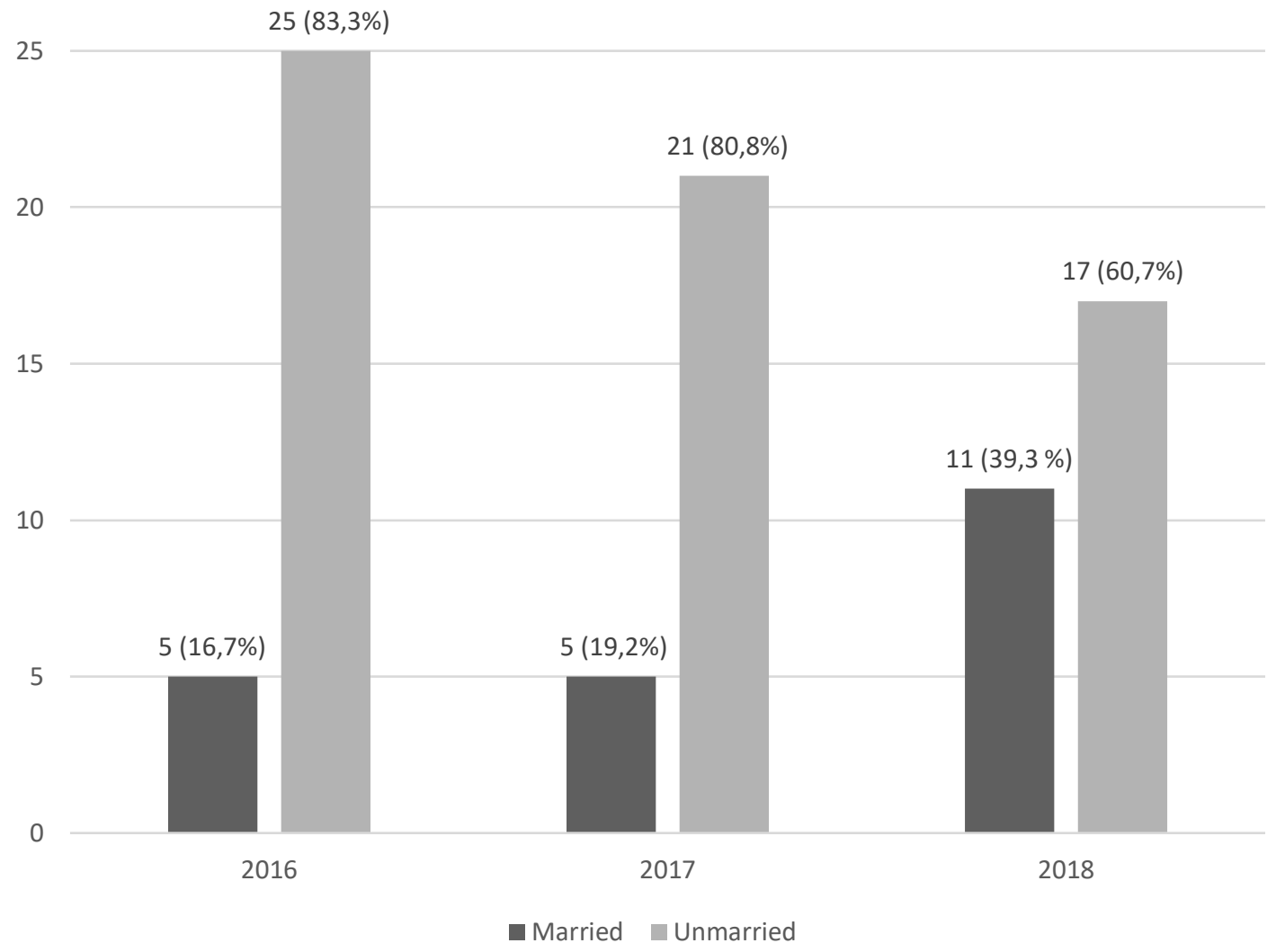

Figure 1. The distribution of marital status of GO patients at the STI Division, Dermatology and Venereology Department, Dr. Soetomo General Academic Teaching Hospital, Surabaya in 2016-2018. 


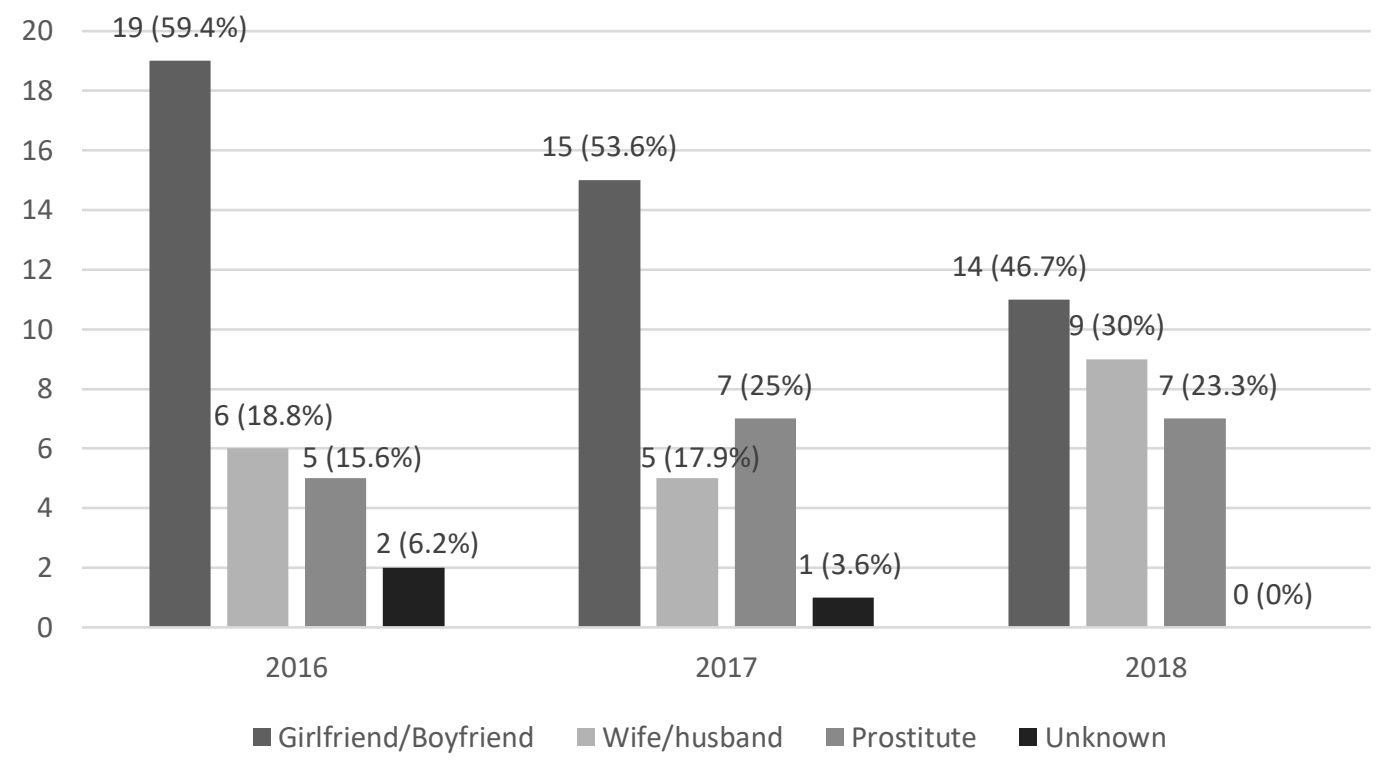

Note: one patient may have multiple sexual partners.

Figure 2. The distribution of sexual partners of GO patients at the STI Division, Dermatology and Venereology Department, Dr. Soetomo General Academic Teaching Hospital, Surabaya in 2016-2018.

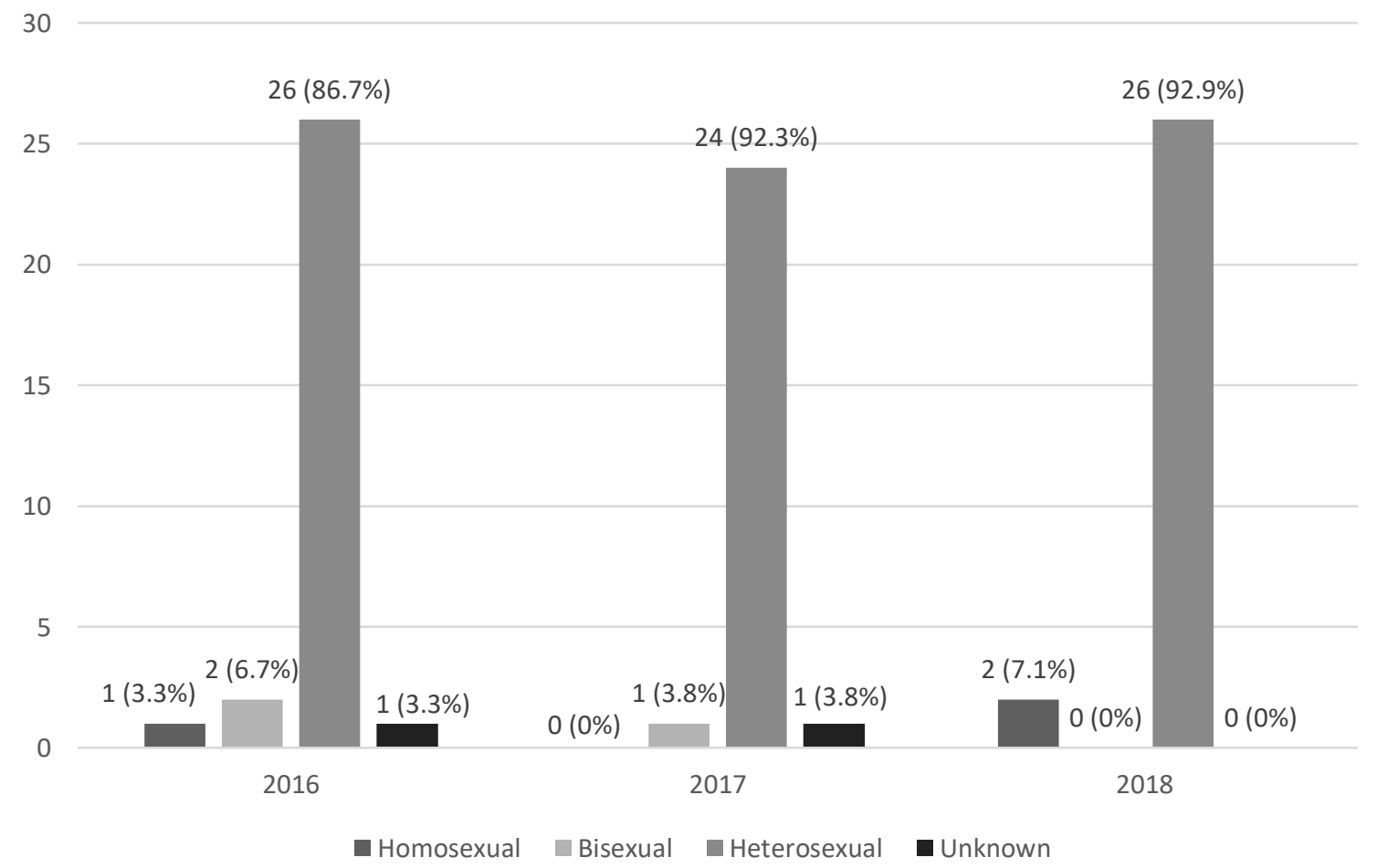

Figure 3. The distribution of sexual orientation of GO patients at the STI Division, Dermatology and Venereology Department, Dr. Soetomo General Academic Teaching Hospital, Surabaya in 2016-2018.

Purulent discharge was observed in all $(100 \%)$ GO patients, followed by dysuria (75.2\%), and fever (3.6). The Gram stain of urethral discharge and potassium hydroxide examination served to support the diagnosis of GO patient. The laboratory examinations resulted in $100 \%$ of polymorphonuclear leukocytes with intracellular Gram-negative diplococci and Clue cells or Trichomonas vaginalis, pseudohyphae and blastospores were not observed. 
Table 1. The distribution of the main complaint of GO patients at the STI Division, Dermatology and Venereology Department, Dr. Soetomo General Academic Teaching Hospital, Surabaya in 2016-2018

\begin{tabular}{lcccc}
\hline & \multicolumn{3}{c}{ Year } & Total (\%) \\
\cline { 2 - 4 } Main complaint & $2016(\%)$ & $2017(\%)$ & $2018(\%)$ & \\
& $\mathrm{n}=30$ & $\mathrm{n}=26$ & $\mathrm{n}=28$ & $\mathrm{n}=84$ \\
\hline Purulent discharge & $30(100)$ & $26(100)$ & $28(100)$ & $84(100)$ \\
Dysuria & $16(53.3)$ & $24(92.3)$ & $24(85.7)$ & $64(76.2)$ \\
Fever & $2(6.7)$ & $0(0)$ & $1(3.6)$ & $3(3.6)$ \\
\hline
\end{tabular}

Note: one patient may have multiple complaints

Gonorrhea (GO)

Sexually Transmitted Infections (STI)

Table 2. The distribution of the laboratory examinations of GO patients at the STI Division, Dermatology and Venereology Department, Dr. Soetomo General Academic Teaching Hospital, Surabaya in 2016-2018

\begin{tabular}{lcccc}
\hline \multirow{2}{*}{$\begin{array}{l}\text { Laboratory } \\
\text { Examinations }\end{array}$} & $2016(\%)$ & $2017(\%)$ & $2018(\%)$ & Total (\%) \\
\cline { 2 - 4 } & $\mathrm{n}=30$ & $\mathrm{n}=26$ & $\mathrm{n}=28$ & $\mathrm{n}=84$ \\
\hline $\begin{array}{l}\text { Intracellular Gram-negative } \\
\text { diplococci }\end{array}$ & $30(100)$ & $26(100)$ & $28(100)$ & $84(100)$ \\
& & & & \\
\hline
\end{tabular}

Figure 4 shows that dual therapy was the most used therapeutic option for GO patients. The most common combined therapy was cefixime plus doxycycline, as reported in $50(78 \%)$ patients, cefixime plus azithromycin in $13(20.3 \%)$ patients, and cefixime plus erythromycin in $1(1.7 \%)$ patient. We also found that $20(23.8 \%)$ patients received single therapies, and cefixime was the most prescribed antibiotic, as reported in $19(95 \%)$ patients.

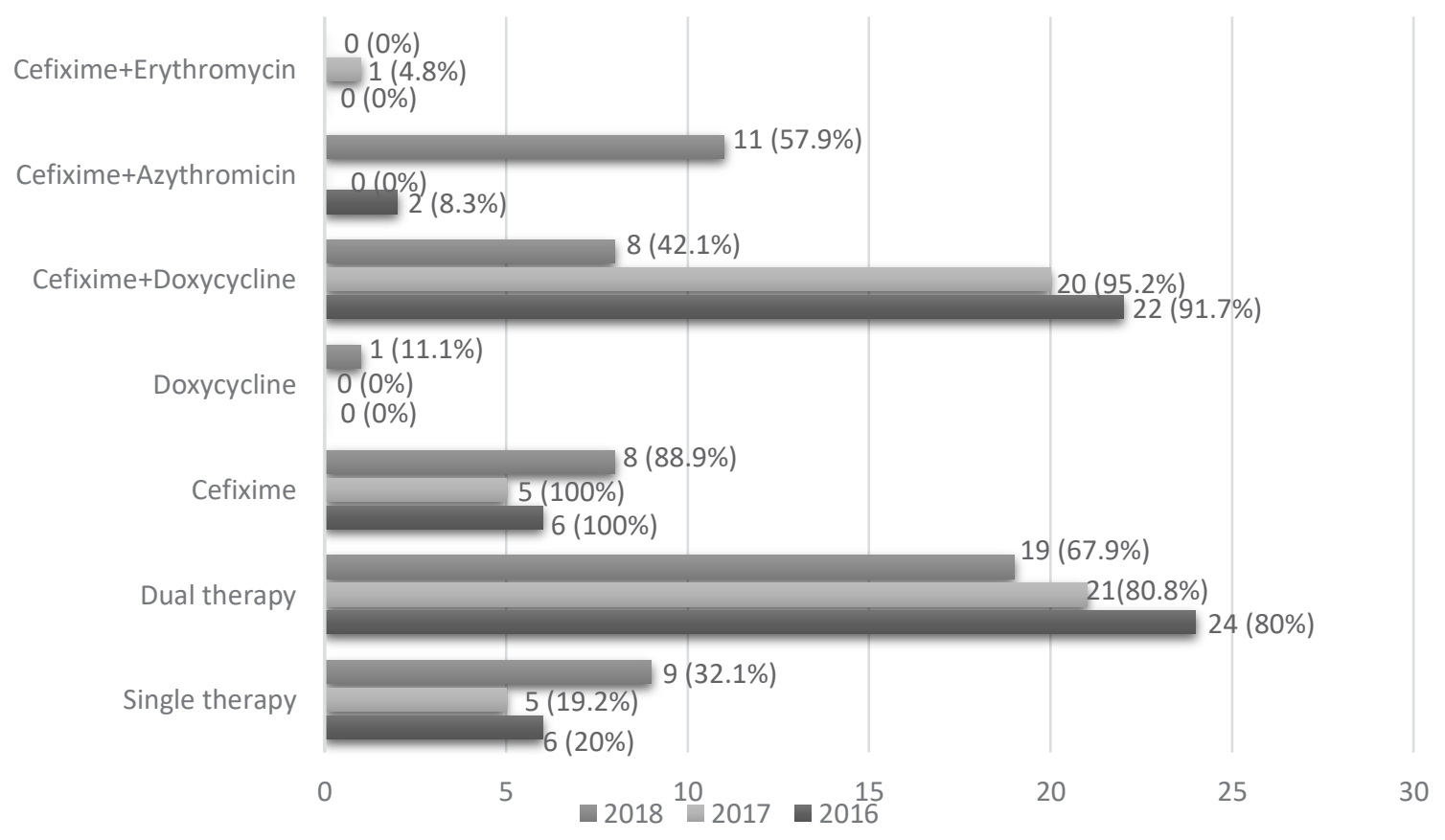

Figure 4. The distribution of GO therapies at the STI Division, Dermatology and Venereology Department, Dr. Soetomo General Academic Teaching Hospital, Surabaya in 2016-2018.

Figure 5 shows that the GO patients mostly did not attend follow-up visits, as reported in 50 $(59.5 \%)$ patients, and only $34(40.5 \%)$ patients attended the follow-up visit. We found that 32 (94.1\%) patients who attended the follow-up visits have recovered, and only $2(5.9 \%)$ patients presented with complications of cystitis. 


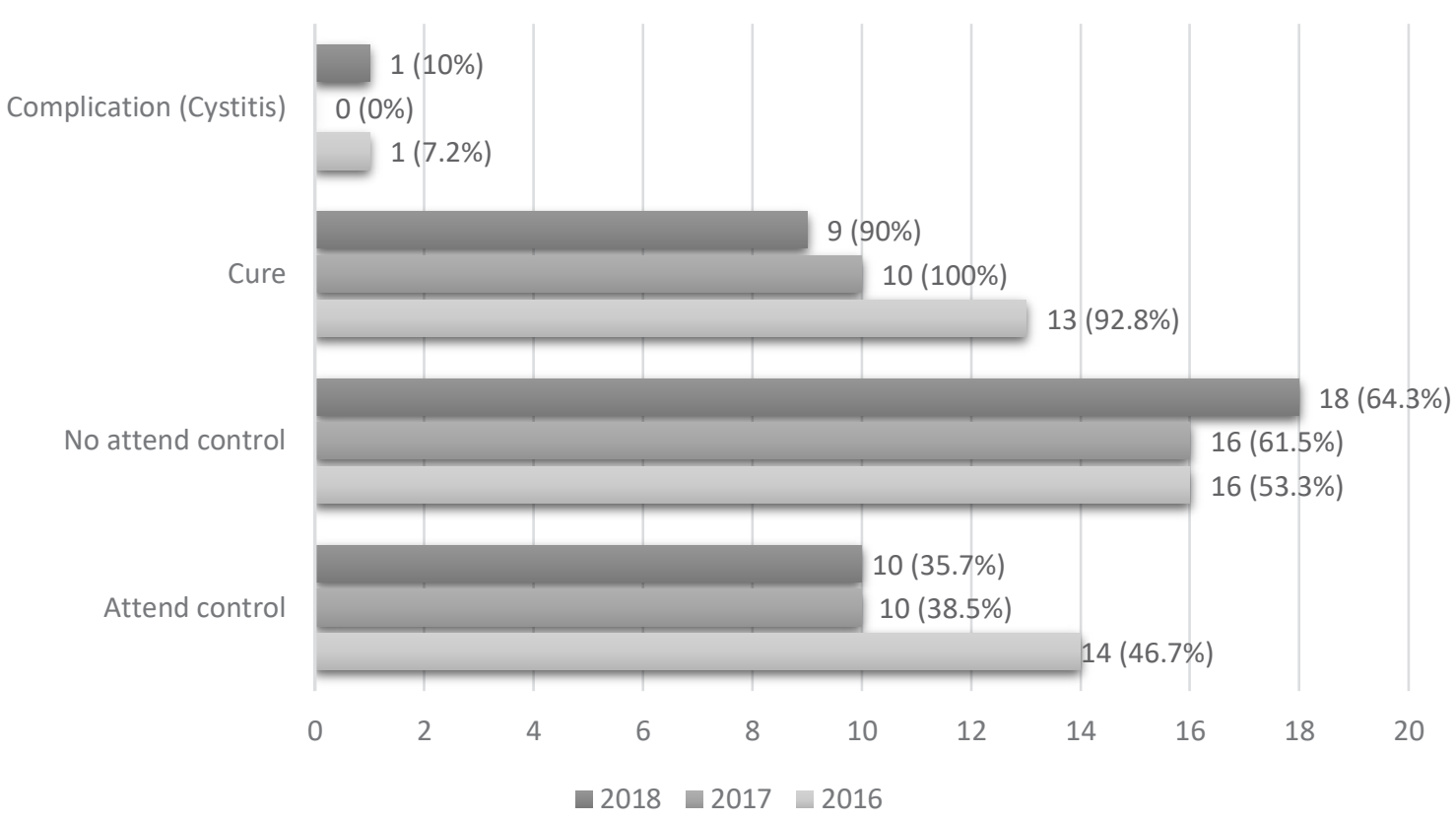

Figure 5. The distribution of patients'follow-up visits at the STI Division, Dermatology and Venereology Department, Dr. Soetomo General Academic Teaching Hospital, Surabaya in 2016-2018.

\section{DISCUSSION}

The total of GO patients contributed to the $3.3 \%$ of the total patients at the STI Division, Dermatology and Venereology Department, Dr. Soetomo General Academic Teaching Hospital, Surabaya. There were 30 (35.7\%) GO patients in 2016, 26 (30.9\%) GO patients in 2017, and $28(33.3 \%)$ GO patients in 2018, totaling 84 patients. A retrospective study by Pitasari confirmed a decrease in total new GO patients from 125 cases $(4.1 \%)$ to 84 cases $(3.3 \%) .{ }^{10,11} \mathrm{We}$ presumed that this was possible because of more accessible health information from the internet, friends, private clinics, private doctors, or health centers.

Most GO patients (44 patients or 52.4\%) were under 17-25 years age group and followed by 25 patients (29.8\%) under 26-36 years age group. In 2013, Wang et al. reported that the majority of GO patients were under $15-25$ years age group. ${ }^{12}$ Teenagers and young adults, under the 15-24 aZge group, are those with sexually active behavior and are generally involved in free sex as they seek self-identity, personal values, and norms.

Multiple sexual partners, sex orientation, and marital status are the risk factors for GO infection. ${ }^{1,11}$ In this study, we found that most patients were unmarried $(75 \%)$ compared to married patients $(25 \%)$. Most of GO patients girlfriends/boyfriends (53.3\%) as their sexual partners, followed by wife/husband $(22.2 \%)$, and commercial sex worker (21.1\%). Additionally, patients may have multiple sexual partners. This was in line with a study by Pitasari conducted in 2013-2015, suggesting that the most GO patients were unmarried (54.8\%) compared to married patients $(45.2 \%){ }^{10}$ Unmarried marital status contributed to the high prevalence of GO as it opens to non-exclusive sexual relationship. ${ }^{13,14}$

We found that most GO patients were males (92.2\%) compared to females (7.1\%), and most of GO patients identified themselves as heterosexuals $(90.5 \%)$. This was in line with the study conducted by Jawas, and it reported the majority of GO patients were males $(90.7 \%)$. Also, a study by Pitasari reported a high prevalence of male GO $(93.6 \%){ }^{10,15}$ Gonorrhea infections in males are generally symptomatic, while GO infections in females are generally asymptomatic or no recognizable abnormality until a complication such as pelvic inflammatory disease (PID) occurs. ${ }^{1,3}$ These motivate males to seek curative treatment to prevent infections also sequela. The high prevalence of GO infection in males relates to occupational and domestic stress, encouraging them to seek instant gratification, in this case, using sexual worker services.

Most GO patients (76 patients or 90.5\%) identified themselves as heterosexuals, and only 3 patients $(3.6 \%)$ identified themselves as homosexuals. This was in line with a study by Rositawati in 2017 , reporting that heterosexual sexual orientation was the highest risk factor $(65 \%)$ for gonococcal infection, followed by homosexual (20\%), and sex with transgender $10 \%{ }^{16}$ The updated epidemiological data published by the Centers for Disease Control and Prevention (CDC) shows increased GO infection in heterosexual males and females. However, additional data showed that GO infections, in particular, are 
concentrated in a specific men-sex-with-men (MSM) community. ${ }^{1,3}$ Such contrast results might be related to the research site and openness to sexual orientation and behavior.

History of the main complaint, physical examination, and direct microscopic examination with Gram stain are the criteria for GO infection diagnosis. Gram stain of a urethral specimen that shows polymorphonuclear leukocytes with intracellular Gram-negative diplococci can be considered to support $N$. gonorrhoeae infection in symptomatic males. This laboratory support has high specificity (>99\%) and sensitivity (>95\%). ${ }^{1,2,14}$ In this study, we found that purulent discharge $(100 \%)$, dysuria $(76.2 \%)$, and fever (3.6\%) were the main complaints. The Gram stain of a urethral discharge served to support the GO diagnosis. It resulted in $100 \%$ of polymorphonuclear leukocytes with intracellular Gram-negative diplococci and no Clue cells Trichomonas vaginalis, pseudohyphae, and blastospores.

The majority of GO patients received dual therapy, as reported in 64 patients $(76.2 \%)$. A combination of cefixime and doxycycline (78\%) was the most prescribed medication, followed by cefixime and azithromycin (20.3\%), and cefixime and erythromycin (1.7\%). On the other hand, we found that 20 patients $(23.8 \%)$ received single therapy with cefixime as the most prescribed antibiotic option (95\%). The treatment of gonorrhea can be challenging as there has been increased resistance of Neisseria gonorrhoeae to several antimicrobials such as sulfanilamide, penicillin, tetracycline, and fluoroquinolone as well as decreased sensitivity to ceftriaxone and cefixime in some countries. ${ }^{1,5,17,18}$ Dual therapy for GO infection has been recommended by CDC since 2010 involving two antimicrobials with different mechanisms, cephalosporin plus azithromycin or doxycycline. It can increase effectiveness and reduce the potential for the susceptibility of antimicrobial resistance. ${ }^{1,3}$ The use of dual therapy can treated coinfection with $C$. trachomatis that frequently in GO patient. Some studies reported susceptible resistance to cephalosporins, especially cefixime. This suggests that dual therapy has a higher efficacy. ${ }^{3}$

Only 34 patients $(40.5 \%)$ attended the follow-up visit. The follow-up physical examination and direct microscopic examination with Gram stain showed that almost all (94.1\%) patients had recovered, and only 2 patients $(5.9 \%)$ had complications of cystitis. This was in line with a study by Pitasari 2015, reporting that 46 out of $125 \mathrm{GO}$ patients did not attend the follow-up visit. ${ }^{10}$ In general, GO patients seek medical treatment, and their health improved. However, in the event of recurrent infection, they would take the previously prescribed medicine without seeking medical treatment. Most infections are results of reinfection rather than treatment failure, indicating a need for improved patient education and referral of sex partners. Clinicians should advise patients with gonorrhea to be retested 3 months after treatment. If patients do not seek medical care for retesting in 3 months, providers are encouraged to test these patients whenever they seek medical care within the following 12 months, regardless of whether the patients believe that their sex partners have been treated. Retesting is distinct from test-of-cure to detect therapeutic failure, which is not recommended. ${ }^{1,3}$

Patients should be instructed to refer their sex partners for evaluation and treatment adequately. All GO patients should be given the education to abstain from sexual intercourse until therapy is completeduntil they and their sex partners no longer have symptoms - to prevent reinfection and curtail further transmission of STIs. ${ }^{1,3,5,17}$ In this study, no complete data on education or treatment of sexual partners were found. It is important to educate patients to refer their sexual partners for examinations and treatments to prevent ping-pong phenomenon. Education and routinely control for gonorrhea should be encouraged and offered to high risk group of GO.

The overview of collected data suggested that most cases were predominantly observed in unmarried heterosexual males under 17-25 years age group. Most GO patients received a dual therapy of cefixime plus doxycycline. Only $40.5 \%$ of patients attended the follow-up visit, and most of them have recovered.

A complete medical record is essential. Patients should be counseled about the importance of seeking medical evaluation to minimize the incidence of reinfection, treatment failure, or complications as well as promote safe sexual behavior, spiritual aspects, and the awareness of other STIs.

The implementation of various models of health education could give good results in risk reduction of GO and STIs prevention relatively quickly. In addition, educations and promotion should be an important part of their counseling.

\section{REFERENCES}

1. Strowd LC, McGregor S, Pichardo RO. Gonore, Mycoplasma, and Vaginosis. In: Kang S, Amagai M, Bruckner AL, Enk AH, Margolis DJ, McMichael AJ, Orringer JS, editors. Fitzpatrick's Dermatology in General Medicine. $9^{\text {th }}$ ed. New York: McGraw-Hill Medical; 2019.p. 3207-12.

2. Hook EW, Handsfield HH. Gonococcal Infections in the Adult. In: Holmes KK, Sparling 
PF, et al. Sexually Transmitted Disease. $4^{\text {th }}$ ed. New York: Mc Graw Hill. 2008.p. 627-45.

3. Centers for Disease Control and Prevention. Sexualy Transmitted Disease Treatment Guidelines. Gonnococcal Infections. MMWR. 2015;64(3):p. 60-8.

4. World Health Organization. WHO Guideline for the Treatment of Neisseria gonorrhoeae. World Health Organization 2016. Available from: http://www.who.int

5. Kementerian Kesehatan Republik Indonesia. Pedoman Nasional Penanganan Infeksi Menular Seksual. Jakarta: Kementerian Kesehatan Republik Indonesia; 2015.

6. Djonic D, Djuric M, Bassioni-Stamenic F, et al. HIV-related risk behaviors among Roma youth in Serbia: results of two community-based surveys. J Adolesc Health. 2013; 52:234-40.

7. Azwar A. Kesehatan Reproduksi Remaja di Indonesia (Adolescent Reproductive health in Indonesia). 2000.

8. Barry P.M, Klausner J.D. The Use of Cephalosporins for Gonorrhea: The Impending Problem of Resistance. Expert Opin Pharmacother 2009; 10(4):555-77.

9. Garcia S, Garcia P. Drug-resistant Neisseria gonorrhoeae: latest developments. Eur J Clin Microbiol Infect Dis 2017;36(7):p. 1065-71.

10. Pitasari DA, Martodiharjo S. Studi Retrospektif: Profil Infeksi Gonore. Berkala Ilmu Kesehatan Kulit dan Kelamin 2019;31:h. 41-5.

11. Puspitorini, D., Lumintang, H. Studi Retrospektif: Profil Pasien Baru Infeksi Gonore. Berkala Ilmu Kesehatan Kulit dan Kelamin 2017;29:h. 59-64.

12. Wang H, L Zhang, Y Zhou, Wang K, Xiaoya Zhang, Jianhui $\mathrm{Wu}$, et al. The use of geosocial networking smartphone applications and the risk of sexually transmitted infections among men who have sex with men: a systematic review and meta-analysis. BMC Public Health 2018;18:p. 110

13. Budkaew J, Chumworathayi B, Pientong C, Ekalaksananan T. Prevalence and factors associated with gonorrhea infection with respect to anatomic distributions among men who have sex with men. PLoS one 2019; 14(4):p. 1-19.

14. Haramaini A, Rachmatdinata, Rasmia R. Prevalensi servisitis gonore pada wanita hamil di Rumah Sakit Khusus Ibu dan Anak Kota Bandung tahun 2015. GMHC 2015; 4(1):47-50.

15. Jawas, A.F, Murtiastutik, D. Penderita Gonore di Divisi Penyakit Menular Seksual Unit Rawat Jalan Ilmu Kesehatan Kulit dan Kelamin RSU Dr.Soetomo Surabaya Tahun 2002-2006. Berkala Ilmu Kesehatan Kulit Kelamin. 2008;20(3):h.217-21.

16. Rositawati A, Sawitri, Hidayati AN. Neisseria gonorrhoeae resistance test against cefixime in gonorrhea patients in Surabaya. Dermatology Reports 2019; 11(s1):8060.

17. Yan J, Xue J, Chen S, Wang Q, Zhang C, Wu S, $\mathrm{Lv} \mathrm{H}$, Lu Y, Van der Veen S. Increasing prevalence of Neisseria gonorrhoeae with decreased susceptibility to ceftriaxone and resistance to azithromycin in Hangzhou, China. J Antimicrob Chemother 2019;74(1):p. 29-37.

18. Hidayati AN. Gonorhea Superbug: A major Concern in Gonoccocal Infection Management. Proceedings of the Malang Dermato-venereology Update 2016 Skin Infections:Must Known Disease. Laboratorium Ilmu Kesehatan Kulit dan Kelamin Universitas Brawijaya RSUD Dr. Saiful Anwar Malang 2016: h. 138-55. 